\title{
Sogneprester kan mer enn å preke
}

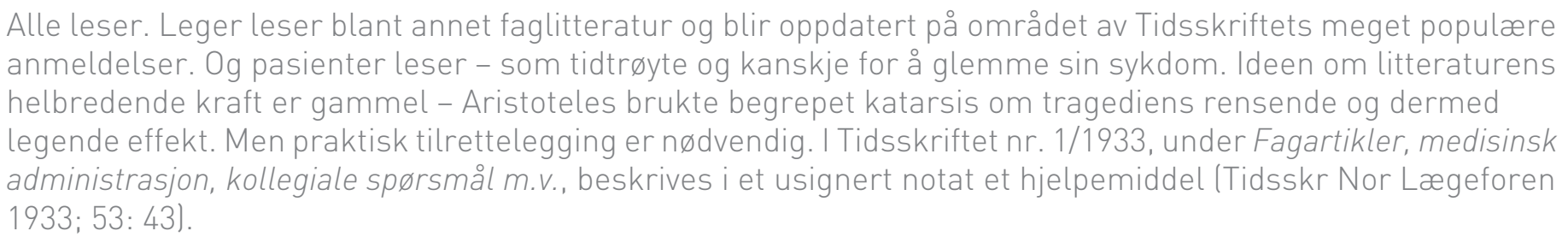

\section{Bokstativ for syke.}

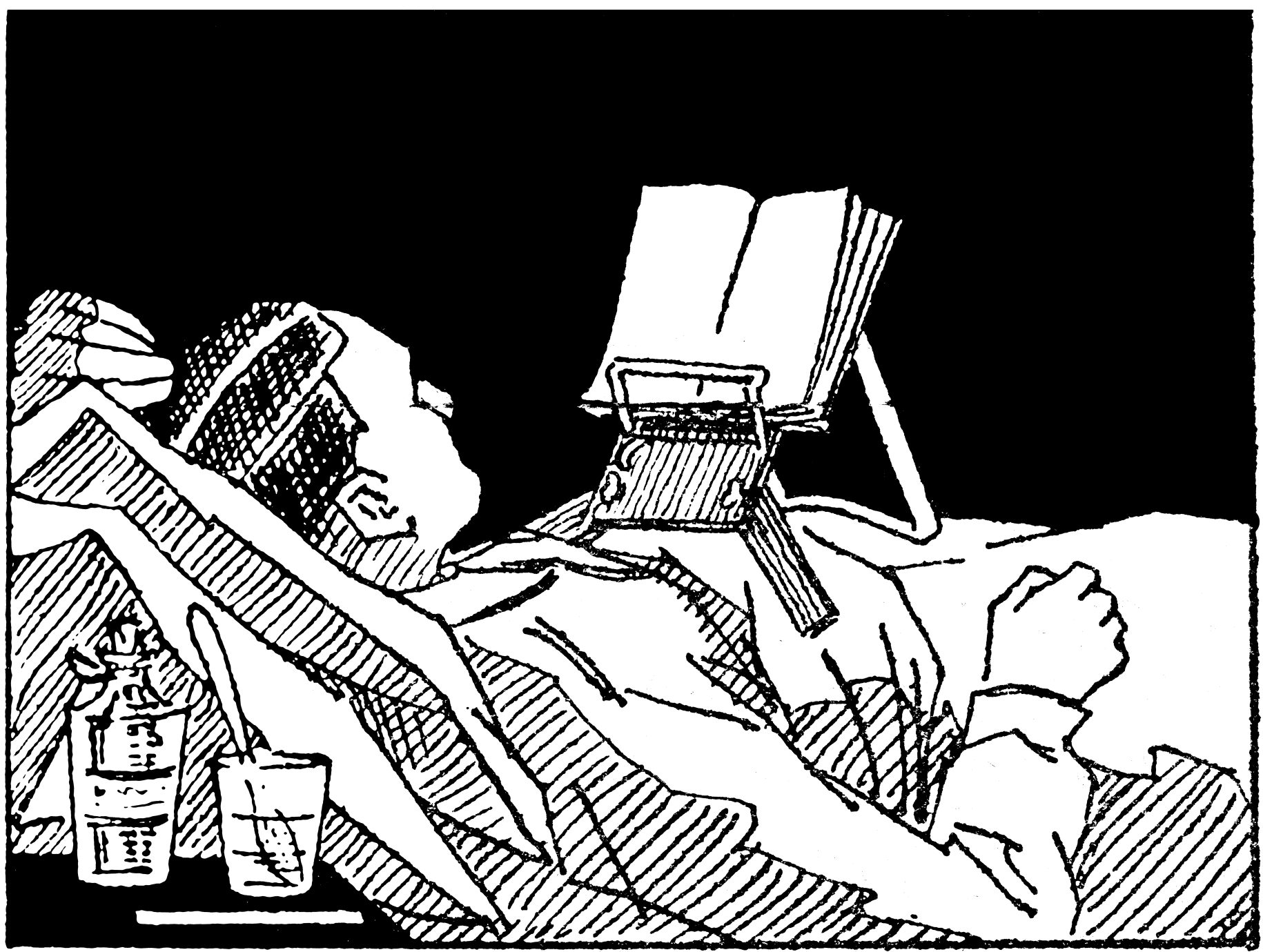

Mange sengeliggende patienter har savnet et praktisk bokstativ. Et sådant stativ konstrueret av sogneprest Bull er nu bragt i handelen og vil sikkert avhjelpe «et lenge følt savn». Stativet er meget hensiktsmessig, praktisk og lettvindt. Det står støtt på et hvilket som helst underlag av sengetepper eller puter og virker ikke trykkende. Boken holdes fast på stativet og er lett å blade i. Armene får hvile. Stativet er prøvet ved forskjellige sykehus med meget godt resultat, hvorfor vi har villet henlede kollegenes opmerksomhet på det. 